\title{
The Role of Green Financing for Renewable Energy Projects in Reducing Jordan's Debt
}

\author{
Dr. Duraid Kamel Al Shabib \\ Economic \& Business Administration, American University for Human Sciences,1006 N. Jackson St. Glendale, \\ CA 91207
}

\begin{abstract}
Energy is the main driver of various economic sectors. Scientific and technological developments in the sources of power generation have a significant impact on the Jordanian economy, especially renewable energy projects. The sources of energy generation cost a large amount of foreign currencies, and it is generating great pressure on the balance of payments and Jordan's debt. Jordan is characterized by the diversity of renewable energy sources; the expansion of green finance is an important component in the increase of renewable energy projects. When a high rate of renewable energy to energy production in Jordan. it leads to a reduction in the import of fossil fuels, reduces the Jordanian debt, and the Jordanian energy security is achieved.
\end{abstract}

Keywords: Green Finance, Renewable Energy, Jordanian Debt

DOI: $10.7176 /$ RJFA/12-22-07

Publication date: November $30^{\text {th }} 2021$

\section{Introduction}

Energy is one of the most critical sectors of the pivot structures affecting the development of society, as it is the primary driver of the various economic sectors. The main advantage of this sector is scientific and technological developments, especially in the field of systems, equipment, and raw materials used, especially renewable energy tools, and its impact on development policies, population movement, economic, social, and urban development. The issue of energy is of great importance in the Jordanian economy. The cost of energy resources is a large sum of foreign currency. Jordan is one of the poorest countries in the world in terms of energy and water generation. Imports of crude oil, oil derivatives, and natural gas increased to meet the needs of the power generation sector by $94 \%$, without getting involved early in introducing more stable renewable energy alternatives in prices and supply. Jordan is one of the energy importing countries, contributing to the amounts allocated to import the sources used in power generation by $20 \%$ to the GDP, which are generated tremendous pressure on the balance of payments. The constant change in prices affects the standard of living of the citizen and the rise in the cost of production in various economic sectors. It requires the search for alternative sources of energy, which are compatible with sustainable development. It responds to the needs of the present without jeopardizing the ability of future generations to meet their economic needs. Failure to use renewable energy exacerbates the financial problem, increases indebtedness and its impact on GDP. Renewable energy is one of the essential alternative sources available in Jordan. The Jordanian government has been interested in investing in renewable energy since 2012 , but renewable energy still contributes $10 \%$ of the total energy mix in 2020 . Jordan is characterized by the diversity of renewable energy sources, which are energy generated from inexhaustible natural sources, namely: wind energy, hydro energy, bioenergy, especially solar energy due to the high average direct solar radiation. Jordan is in the socalled solar belt countries, as the number of sunrise days on The Kingdom reaches 316 days per year, with an average of 8 hours per day. Wind energy is one of the best sources of renewable energy to generate electricity in the Kingdom. Many regions are distinguished by wind speeds ranging from 7-8.5 meters per second, which is suitable for building stations that use wind energy to generate electric power. Green finance is one of the main obstacles in the expansion of the use of renewable energy. To increase the value of financial flows with priority given to sustainable development projects, development initiatives, and green products are reduced Jordan's imports of energy sources for fossil fuels.

On the other hand, Jordan's debts will increase to $\$ 37$ billion, Which is equal to $110 \%$ of GDP, the percentage of imports of power generation sources in Jordan rises to $20 \%$ of GDP annually, in addition to the unforeseen cost that the environment is exposed to because of the use of oil and gas in power generation. All these reasons have led to an interest in studying the importance of expanding green finance. Investment financing for renewable energy projects aims to reduce the depletion of foreign currencies, improve the Jordanian balance of payments, and reduce debt and achieve Jordanian energy security.

\section{Research Methodology}

The researcher studied contemporary trends in increasing green finance and its role in spending on renewable energy projects. The researcher linked renewable energy with the impact on Jordan's debt. The researcher relied on written research on the subject and a survey of published works from expert authors and relied on real data from its original sources. The case of green finance in Jordan was selected as case study material for further 
analysis. The research will explore ideas and formulate a theory to summarize, analyze, conclusions and recommendations for the development of financing renewable energy projects in Jordan.

\section{Objectives \& Importance of the Research}

The importance of the study is represented in two aspects:

\section{- Scientific importance}

The scientific importance of this study will fill the gap in previous studies that did not address the effect of green finance in increasing the production of renewable energy and reducing debt in Jordan. The challenges are facing Jordan for increasing the volume of green finance.

- practical importance

The practical importance of this study comes from the fact that debt is one of the most critical sustainable problems in the Jordanian economy due to the costs of paying debt service. One of the most important sources of the annual need for debt is the import of fossil fuels from outside Jordan, which generate electric power in a large proportionexpanding green finance on increasing investment in renewable energy projects and reducing the size of Jordanian indebtedness.

The objectives of the study are to try to identify the following:

. The reality of green finance in the Jordanian financial and banking system

. Presenting the most significant obstacles that prevent the expansion of green finance.

. The impact of expanding green finance in increasing renewable energy projects.

The effect of increasing the implementation of renewable energy projects, thus reducing the import of fossil fuels, and limiting the increasing indebtedness.

\section{Research Problem and Questions}

There is a rise in Jordanian indebtedness; the high cost of imported energy has contributed 3 billion dollars annually. The annual investment required in the renewable energy sector is estimated at one billion dollars annually. The research problem is focused on studying the importance of expanding and accelerating the contribution of the Jordanian financial and banking system to green finance, developing the implementation of renewable energy projects, measuring the assistance of these projects to reducing imports of energy sources and their impact on the Jordanian balance of payments and the Jordanian debt. Based on the above. The researcher will therefore try to answer the following questions:

4.1 What is the impact of increasing the contribution of green finance in advancing renewable energy projects? 4.2 What is the effect of increasing green finance in raising the value of electric power production based on renewable energy?

4.3 What is the effect of expanding renewable energy on reducing imports of fossil fuels and reducing Jordan's debt?

\section{Literature Review}

\subsection{Green financing}

Green financing for renewable energy projects is combines money, business, environmental preservation, and sustainable development. Attention should be paid to the development of the renewable energy industry and its financial sectors. A specific analysis is an internal mechanism to communication, mutual penetration, and mutual influence between the two sectors.

This goal is achieved by participating in many agencies, including government, individual consumers and companies, producers and investors, financial institutions, and financial lenders. It aims to increase the level of financial flows from (banking, microcredit, insurance, and investment) and from the public, private, and non-profit sectors to sustainable development priorities. Financial savings can be achieved through environmental conservation and sustainable development or combining the two goals (Wang, Qiang Zhia, 2016).

There is no accurate and comprehensive definition of green finance by the international financial institutions, the International Finance Corporation. If there are some definitions, they differ according to their objective. (Spratt Griffith-Jones ,2013) Some consider green finance as climate finance, other environmental goals such as reducing industrial pollution and climate change activities, water sanitation, or protecting biodiversity. Investing in projects that reduce or avoid greenhouse gas emissions (Flynn ,2013) Green finance refers to the flow of financial investment into projects for sustainable development initiatives, environmental products, and policies that encourage a more sustainable economy.( Höhne, Khosla, Fekete, Gilbert ,2012).

The Green Finance Study Group defines green finance as "the financing of investments that provide environmental benefits in the broader context of environmentally sustainable development" (Finance, Synthesis Report G20, 2016). Green finance refers to projects related to increasing investments in projects and activities based on the use of renewable energy, developing the use of natural elements, and making the economy more amenable to green management (Chaudhry and Bhattachary, 2006). 
The Organization for Economic Co-operation and Development defines green finance as financing that aims to "achieve economic growth while reducing pollution and greenhouse gas emissions, minimizing waste, and improving the efficiency of the use of natural resources. (Zadek and Flynn ,2013). Islamic finance has contributed in ways like the core principles of sustainable finance, financial stability, economic growth, poverty alleviation and wealth distribution, financial and social inclusion, and environmental preservation. Therefore, Islamic finance has allowed taking advantage of the similarities to become a natural way to increase the elements of green finance. (Persiaran Bukit Kiara, \& Others ,2019). Green finance is a strategic program to engage the financial sector in contributing to the transition process towards low carbon and efficient use of natural resources. Achieving green growth is a promising strategy to promote economic growth. It aims to shape existing economic processes by environmental principles, create additional employment and income generation opportunities, reduce the impact on the environment, achieve sustainability, and reduce resource depletion. (Parvadavardini Soundarrajan Oundarrajan; Nagarajan Vivek, Agric, 2016). Through the definitions, it can be concluded that green finance is the flow of funds to sustainable development projects, the production of pollution-free projects to improve the environment, the economy, and the preservation of natural resources. For this research, green finance can be defined as financing that aims to increase investments in energy production projects. To reduce the use and import of fossil fuels, improve the balance of payments position, reduce debt, and contribute to reducing pollution. Feasibility studies have proven that switching to green finance is the solution to ensure continuity in a changing world, despite some risks. Still, this financing opens new opportunities to face challenges such as climate change, water, energy, and green economy, problems related to global warming resulting from increased carbon dioxide emissions. The shift must be towards alternative energy sources other than fossil fuels, so the banking sector must adapt and change towards the era of financing sustainable development and green finance (http://alrai.com/article/10454844). The various renewable energy sources have developed their exploitation, including solar energy, wind energy, thermal energy, ground energy, and hydropower, to increase the percentage of renewable energy from the total energy mix. The expansion of renewable energy is in transportation projects, industrial, agricultural, and service projects. Renewable energy contributes to reducing the oil import bill, diversifying energy sources, protecting the environment, and achieving energy security. It is a series of administrative means that require commercial banks and other financial institutions to conduct research and perceptions to finance environmentally friendly energy production projects, participate in environmental protection and achieve sustainable development (Abdul Hakim Mustafa Joudeh, 2018) Preparing independent plans for the renewable energy sector must be within the sustainable development goals, with the aim of everyone obtaining sustainable energy at an affordable cost and providing appropriate sources of financing that are compatible with the characteristics of green investment to achieve savings. Green finance is the diversification of financing tools for financial and banking institutions keen to integrate sustainability standards into their products through green loans and accounts designed to finance environmentally friendly projects, particularly renewable energy projects. Green finance is used synonymously with green investing. (Bloomberg New Energy) which includes costs such as project preparation and acquisition of land, green products, and equipment. Green finance standards should be applied to all lending decisions, including ex-post control and risk management processes. Green finance aims to increase investments that preserve the environment-using low-carbon technologies, projects, industries, and businesses. Investments must contribute to reducing the vulnerability of goods and people to the effects of climate change. Green finance is based on the principle of green credit. The decisions of the World Conference on Renewable Energy in 2015 can be used to increase efforts towards investing in renewable energy and increase the actual contribution rate by developing strategic plans towards increasing the contribution of renewable energy from the total energy mix.

5.2 The role of banks and the financial system in green finance:

Finance plays an active role in implementing investments in renewable energy, financial and banking institutions is increasing their contribution to green finance. Consideration should be given to reducing costs and risks of green finance, increasing returns, and perfecting the financing mechanism. Considering green finance is an essential part of the infrastructure for green investment growth that consists of the green technology development company, the government, the investor, and the consumer. (Doh, 2009). Green finance aims to improve the efficiency of power generation and the use of the smart grid, including the conditions of the legal, economic, and institutional framework, legislation of laws and regulations, which push investors to participate more with companies specialized in the production of renewable energy and environmentally friendly projects (Ramadan Iman et al. 2019). The financial system plays a role in increasing the windows of green finance by establishing the Green Climate Fund. Structured green funds or financial instruments for green investments, such as the issuance of green bonds characterized by the low cost of capital and interest, is a pre-tax fee characterized by relatively low-risk bonds issued for rather long periods. Bonds can be issued by the government and financial and banking institutions. Bonds tend to provide higher profitability, liquidity, and stability that meets the diversity of investors. Bond markets give the advantage of easier entry and exit for investors, thus increasing liquidity. Collected from these 
bonds should be spent on renewable energy and sustainable green projects exclusively. Green bonds can be used as tools to hedge risks from the environment and climate change. Some green bonds may raise funds for a specific project. National or local government subsidies give preferential benefits by adopting policies related to green bonds, such as lower investment costs, more favorable taxes, etc. In addition, green bonds have stricter disclosure requirements than regular bonds so that investors can invest with a low-risk advantage, meet the requirement of social responsibility, and can get benefits; for example, the European Investment Bank issued the first global bond for climate awareness and financing of renewable energy projects Improving energy efficiency, since 2013, the international green bond market has witnessed significant development. (EIB, 2007). One of the most important reasons for the decline in investment in renewable energy is the lack of an appropriate financing system. It considers the requirements of its production and the demands of investors. Creating a renewable energy industry is a considerable capital need. Due to the high payback period, it is necessary to innovate an appropriate financing method with the development of existing financial instruments and new ones. The result of fiscal policy is to find a new way to obtain funds and allocate them for green investment; it has become a necessity. Policies supporting the development of green finance are needed to deal with the objectives of environmental protection. (Wang, Qiang Zhia 2016,) Providing support is through renewable energy purchase agreements for long periods, specifying a clause on environmental donations linked to traditional sales deals and other environmental services, environmental leasing, and policy techniques adopted in green finance can be provided. ( Riaz Uddin \& others, 2021).

\section{Requirements for the expansion of green investment financing}

4.2.1 Green banks, or a division of established banks, play an influential and vital role and contribute to the funding of green investment projects. Green loans are given at concessional interest rates geared towards providing support for investment in green projects and assets (Mudra, Journal of Finance and Accounting),

Banks can design an environmental information system. Offers for products to meet customer needs of green finance and long-term desire to achieve sustainable development.(Parvadavardini Soundarrajani, Nagarajan ,2021), ( Höhne et al. 2012).

4.2.2 Central banks are doing their role in greening financial systems. It is developing legislation to encourage green finance and facing environmental, social, and institutional governance risks. It is the intervention of the ecological and social system in governance, granting advantages to green reserve requirements by central banks. It is based on reducing the required reserve rates on green assets and favoring green investments. (Palesa Shipalana, 2020).

4.2.3 The financial and legislative system is established to achieve the growth of the market for green financial products and services, such as environmental leasing, which is one of the green financial products, providing environmentally friendly technologies at preferential prices. The use of public capital is to provide credit enhancements for joint public-private investment, allocate resources towards a sustainable and green economy, invest in environmentally friendly equipment (Harris, 2005), direct investment decisions, and create and allocate credit through monetary as microeconomic policies. And the overall economy. Green finance is financial assistance for green development to achieve growth and to give a role to finance sustainable development (UNEP FI, 2011). A clean energy tax levied by the Ministry of Finance, a revenue stimulus tax for green investments, efficiency restoration schemes, and environmental donations. Greening the financial sector, financing is in specific areas of green investment, and activating stock exchanges, economic policy tools, and the regulatory environment are involved, creating market-based mechanisms to motivate companies to reduce risks. The Companies Law is added to it regarding large companies that contribute a certain percentage of their profits to green bonds to encourage participation in green investment.

4.2.4 Investments in renewable energy are accelerating and preparing regulations and engineering business, industrial, agricultural and services towards green investments, investment in infrastructure as an engine for green economic activity, modern, flexible, sustainable, and adaptable infrastructure. (Palesa Shipalana, 2020).

4.2.5 Innovative tools and methods for green finance

Debt and equity swaps are used in the financial sector. Green credit policy tools are used, such as differential rediscount rates, offering credit to green investments with pre-discounted bills at lower loan rates. Lending is at subsidized interest rates when priority loans are pre-discounted in the Central Bank on concessional terms (Chen, Zhixia \& Others,2018). Renewable energy portfolios are established for green finance, preferably by banks. Funding divisions for renewable energy projects, Specialized Agency for Renewable Energy Development, are created to raise funds to finance clean environment initiatives and green mortgage. Hedging tools are used against risks using exchange-traded catastrophe options. Hedging is used against physical hazards and includes damage from weather events and broader climatic trends. Economic disruptions are caused by climate policies, technology, and the market is moving in the context of adapting to a less carbon-intensive economy. (https://www.imf.org/ar/News/Articles,2019).

- Green insurance is used to provide complete coverage with low premiums to cover some losses resulting from 
climate change. The International Finance Corporation can ask for its help as a guarantor or an organized investor to reduce risks (International Finance Corporation, 2006).

\subsection{Renewable energy}

Renewable energy is proving efficient in production and lower costs. In the long run, carbon emissions harmful to the environment are reduced and raise the level of energy security, which called some to add environmental and social sustainability to Friedman's list of the main objectives of the economic and financial policies. The implementation of innovative energy restructuring will reduce the energy intensity in the GDP, the share of renewable energy sources will increase, and reduce the import and consumption of fossil fuels, providing an adequate level of energy independence. Complex global innovations are being absorbed in renewable energy, energy efficiency standards and types are being defined. The results of scientific and practical research are predictable (Liptak, O; Baula, 2021) to ensure the localization of this technology and reduce power generation costs. Active investment in renewables requires assistance in infrastructure investments. (Karim, Mohammad Ershadul\& Others,2019) ;( Muhammad-Sukki, Firdaus; Nurul Aini Bani, 2019). The cost of electricity using renewable energy technologies is closely related to the cost of financing. The expansion of the use of these technologies is the continuation of the competitive electricity market in favor of renewable energy production technologies. This competition will reduce the risks of financing renewable energy projects. The financial instruments will fit the needs of funding renewable energy, scientific and technological development (Wang, Qiang Zhia, 2016). The study compares energy production; it showed that the use of solar energy leads to a decrease in the cost of electricity generation from 49 euros/kilowatt-hour for fossil fuel sources to 41 euros/kilowatt-hour for renewable energy sources. (Upeksha Caldera \& others, 2018). Another study showed the positive effects of moving to a $100 \%$ renewable energy system would reduce the amount of greenhouse gas emissions from about 24 million tons of carbon dioxide equivalent to zero (Azzuni, A.; Breyer, C. 2020). Solar energy is used in low-income housing. Contribute to sustainable development. The local economy is protected from changes and political fluctuations in the world. Facing the prospects of oil depletion and constant price changes Reducing the cost of energy will increase the competitiveness of the industrial sector and other sectors in the market. It can be a source of income when exported. It is used to purify polluted water and contribute to providing a better environment. It is used in the distillation of saline water and qualifies it for drinking and farming at low costs. Jordan's consumption of electricity for the year 2019 in all sectors was $16,186,000,000 \mathrm{kWh}$. It needs to import 4,102 billion kg of diesel and gas, with a value of 1,639 billion dollars (http://www.unitjuggler.com/convert-energy-from-boe-to-kWh HTML). Jordanian households consume the largest share of electrical energy with $46 \%$ of electricity, the industrial sector $22 \%$, water pumping $16 \%$, commercial activities $14 \%$, and street lighting $2 \%$. It was found that the level of energy security for Jordan increased by $40.5 \%$, where it ranked 118 out of 183 countries in the world (Azzuni, A.; Breyer, C 2020). Jordan is characterized by a geographical and climatic location that provides clean and renewable energy sources: solar energy, ground energy, and wind energy; solar energy falling on Jordanian lands, and the number of sunny days is 316 sunny days. This means that Jordan has an area that can be invested in renewable energy projects, the urgent and strategic need. It is for the sustainability of this area and the projects built on it. The importance of renewable energy in Jordan comes as it is a permanent, low-cost, and inexhaustible source of available energy, which does not result in pollution compared to the specifications of Jordanian diesel with a low cost of maintenance. It is a strategic goal that ensures the functioning of the internal energy market, ensuring the security of energy supplies. Enhancing energy efficiency, energy saving, environmental preservation, and decarbonization in addition to lowering its cost (Hussam Hussein, Nooh Alshyab, 2020) Jordan's production during 2019 of renewable energy, which includes wind, solar, and water energy, increased to 2996.9 MW compared to 690.4 MW in 2016. It achieved a growth rate of $247 \%$ (National Electricity Company Annual Report 2019). The contribution of solar energy to Renewable production energy is $69.4 \%$, wind energy is $30 \%$, and hydro energy is $0.6 \%$. Investment in renewable energy projects is still going on. The renewable energy project started in 2013. (https:/www.nepco.com.jo/store/docs/web, 2019). Renewable energy projects have been completed. Several energy purchase agreements have been concluded to establish future projects in the field of renewable energy. Solar energy is used to cover the consumption of mosques and homes. The hotel, industrial, and some universities sectors were more comprehensive according to net metering and transit systems (Energy and Minerals Regulatory Authority, 2021). Some local banks finance the renewable energy sector in Jordan; As the Jordan Ahli Bank, in cooperation with the Central Bank of Jordan, grant an incentive interest rate, a partnership agreement between the Renewable Energy Promotion and Energy Rationalization Fund of the Ministry of Energy and Mineral Resources was signed to support the financing of renewable energy projects through; Granting revolving loans, guaranteeing loans and reducing risks, technical support, cash financing, support through soft financing programs. The Jordanian Competitiveness Program is funded by the United States Agency for International Development and is directed to support the renewable energy sector in Jordan. There is also investing from the European Union. Wind farms, hydroelectricity, and solar energy farms are alternative sources of renewable energy that are underutilized in Jordan. They can provide sustainable local energy, primarily for agricultural purposes (pumps, heating plastic houses, etc.). 
The electrical energy consumption of water pumps in Jordan is $16 \%$ of the total electricity consumption. The use of renewable energy reduces the cost to reach 150 fills after converting pumps operating on electricity to plants that work on solar power or other renewable energy sources. (Albaali1, Mohammed Shahateet \& Others ,2020).

\subsection{Jordan's Debt}

The accumulated debt is a burden on the country's economy as deficits more than its financial capabilities. This debt is prevented from expanding investments and development (Myers, 1977). The value of debt service (interests and installments) will go to the lenders. Debt burden theory is the probability that future debt will exceed a country's ability to pay; Debt servicing costs will further reduce domestic and foreign investment, and the expected rate of return from productive investment projects will be too low to support the economy and development (Krugman,1988), due to the terms and conditions of the debt agreement that include the priority of debt service repayments that change because of higher interest rates. If The level of debt has exceeded the state's ability to pay, it is expected that debt service will be an increasing function of the country's economic growth level (Adedoyin et al., 2016). Several studies are confirming that the high external debt burden impedes economic growth.) (Rifqat and Othman,2012, Mukui, 2013) (Saxena \& Shanner, 2015, Akram, 2016, Shkolnik \& Koelu,2018, Monogbe, 2016). The current generation that fails to service the acquired loans will lead to a more significant debt burden on the next generation. The dependency theory confirms this, Which shows that dependence on external funds will lead to an increase in the flow of money (debt servicing) that drains meager resources from highly indebted countries and impeding their economic growth. (Ijirshar, Joseph, \& Godoo, 2016). The high burden of accumulated debt in Jordan and the high indebtedness as a percentage of GDP would affect economic growth, enhancing adverse effects on sustainable development. The sustainability of the debt may lead to the collapse of the economy in the end. The borrowing process is controlled by a combination of internal and external factors; Economic factors, the political conditions surrounding the country, the level of economic growth, the volume of state revenues and public expenditures, the volume of imports and the current account deficit, the decline in foreign exchange reserves and workers' remittances outside the country. The aggravation of the Jordanian public debt is one of the most important economic and financial problems facing the Jordanian economy. It is expected to expand over time. The level of domestic production is declining, growth rates are falling, the unemployment rate is high, and the imbalance rate in the general budget for the year 2019 reached 18.5 percent, due to the increase in Current expenditures, fluctuations in grants and foreign aid, and a significant increase in the tax burden. The deficit in the Jordanian trade balance is 10,860 billion dollars for 2019, the import of fuel for electricity generation is 1,640 billion dollars, the percentage of the import value of power to generate electricity is 16 percent of the deficit in the trade balance; these imports are 464 percent of the annual external debt Added to Jordan for the year 2019, that the transition to entirely renewable energy will lead to the absence of the need for additional yearly borrowing. The Jordanian public debt is expected to reach 35.7 billion dollars in 2021, an increase of 7.4 percent and a rate of 110 percent of GDP by the end of 2021 (The Annual Report of the Jordanian Banks Association 2020). This will add new burdens to the Jordanian economy.

\section{Discussion and Conclusion}

The first question: Is there a relationship between increasing the financing of renewable energy projects and increasing investment in renewable energy projects?

The world requires 350 billion dollars to finance renewable energy projects, 15 percent of governments and organizations fund this need, the contribution of the private sector is necessary with the bulk of the financing, the financing gap is 70 billion dollars for renewable energy projects (Munitlak-Ivanovic \& Others, 2017) Financing plays an active role in increasing investment in renewable energy projects for various reasons: capital-intensive projects, the modernity of this sector, long payback period, and risks. These reasons lead to the the reluctance of banks and the private sector to finance and invest in renewable energy projects without support. This has led to limited capital-intensive renewable energy projects. (Thomas Shinko and others, 2019).

One of the studies used the double-difference method on the effect of green credit policy on financing renewable energy projects, and it showed that green companies were able to obtain more credit compared to traditional companies, lower financing cost and achieved Pareto improvement in the allocation of financial resources (Guangyou Zhou \& Others,2021). The Jordanian government plans for renewable energy will constitute 14 percent of the energy produced by 2030. Investments are in renewable energy projects in Jordan from the participation of countries that contribute funds to Jordan, such as the European Union, the World Bank and the US Agency for International Development, in addition to the central bank and the private sector Jordan, Jordan invested in renewable energy projects for the period from 2012-2020, an amount

of $\$ 3$ billion, which contributed to the generation of electric power of 2,400 megawatts, constituting 11 percent of Jordan's total electric power in 2020, foreign funding contributed to financing 23 percent of Renewable energy projects, government, and private sector 73 percent. (Type: //www.memr.gov.jo). Climatic conditions are available for solar and wind energy, but there is a lack of infrastructure and plans, a lack of specific work tools, 
difficulties in entering the newly developed renewable energy market, and a lack of local funds, which means the presence of financial obstacles and difficulties in attracting foreign investment in this sector. (Karatayev ; Clark ,2014) ( Assel K. Kozhakhmetova \& others, 2019).

It is also noted that the dependence on foreign support and international organizations is 23 percent, while the global average is 15 percent.

The second question: Is there a relationship between increasing electricity generation from renewable energy, reducing costs, and importing fossil fuels?

The assessment of financial efficiency and environmental impact generates electric power from a traditional energy source compared to renewable energy. Studies have proven that.

Renewable energy systems have better efficiency because they do not use fossil fuels as inputs in power generation. Fossil fuels are the high cost of import and the cost of treating emissions carbon dioxide and environmental protection. (N Leela Prasad, \& Others, 2021). The results indicate that in each energy portfolio diversification scenario, bioenergy, wind energy, and solar energy play a role in reducing fixed and operational costs, the most important of which is the cost of fossil fuels. In addition, renewable energy has the highest efficiency in terms of increased production with the lowest prices and carbon emissions. (Vidal-Amaro, J J\& Others, 2015), (Zong Woo Geem \& Others, 2016). The study of Abdelrahman (Abdelrahman Azzuni; and Others, 2020) has proven that the use of renewable energy in electric power generation leads to a reduction in the annual cost of energy from 78 euros/megawatt-hour to 61 euros/megawatt-hour due to the removal of greenhouse gas emissions, generating opportunities new work. Thus, raising the level of energy security, reducing costs, and protecting the environment and health. Another study suggested that Jordan should use a 100\% renewable energy system by 2050. Expansion of renewable energy projects reduces the value of imported energy sources and establishes energy security( Liutak, O \& Others,2012). The data for the year 2020 indicate that the value of importing fossil fuels in Jordan to produce 20,952 megawatt-hours of electricity amount to 1,077 billion dollars (National Electricity The company, 2021). This means if the production of renewable energy in Jordan rises to 10,000 megawatts/hour, this will reduce the cost of importing fossil fuels by 514 million dollars annually, which will lead to the stability of the cost of electric energy for the individual consumer and in the various productive sectors. Table No. (1) shows the effect of fluctuation in the prices of imported fuel on the cost of producing kilowatt-hours in Jordan, where we note an increase in cost by $129 \%$ for the year 2014 compared to 2010 and the continuation of the increase in cost due to the increase in the price of fuel used by $36.8 \%$ for the year 2018 compared to In 2010, despite the decline in imported oil prices.

Table 1. The average price of fuel and the cost of producing kw/h of electrical energy in Jordan 2010-2018

\begin{tabular}{|c|c|c|c|}
\hline Year & $\begin{array}{l}\text { average price of fuel } \\
\text { used }\end{array}$ & $\begin{array}{l}\text { average cost per kw/h } \\
\text { Fills/kWh }\end{array}$ & percentage change to 2010 \\
\hline 2010 & 44.11 & 68.27 & $100 \%$ \\
\hline 2012 & 123.59 & 145.65 & $113.3 \%$ \\
\hline 2014 & 139.34 & 156.6 & $7.7 \%$ \\
\hline 2016 & 37.55 & 73.55 & $36.8 . \%$ \\
\hline 2018 & 82.82 & 93.43 & \multicolumn{2}{c}{} \\
\hline
\end{tabular}

Source: Jordan Electricity Company.

Table No. (2) shows that the imports of gas and fuel oil are declining as sources of electric power generation, from 4184 million $\mathrm{kg}$ in 2018 to 3393 million kilograms in 2020, with a decrease of $18.9 \%$. At the same time, the production of renewable energy has increased from 753 megawatt-hours in 2018 to 2,400 megawatt-hours in 2020, with an increase of $218.7 \%$. This confirms the conclusion when electricity generation from renewable energy increases as the import of fossil fuels decreases.

Table 2. Importing gas, fuel oil and producing renewable energy in Jordan 2016-2020.

\begin{tabular}{|l|l|l|l|l|l|}
\hline year & 2016 & 2017 & 2018 & 2019 & 2020 \\
\hline $\begin{array}{l}\text { Importing gas and fuel oil } \\
\text { (million kg) }\end{array}$ & 3831 & 3820 & 4184 & 4109 & 3393 \\
\hline $\begin{array}{l}\text { sustainable energy } \\
\text { (MWh) }\end{array}$ & 412 & 515 & 753 & 1783.1 & 2400 \\
\hline
\end{tabular}

The table was prepared by the researcher based on the data on the memr.gov.jo/AR/List 2021.

The third question: Is there a relationship between the decline in fuel imports due to the increase in renewable energy and the decrease in Jordan's debt?

The deficit in Jordan's trade balance amounted to 9,080 billion dollars in 2020, the import value of oil and oil derivatives is 3,575 billion dollars, or $39.3 \%$ of the value of the deficit (Jordanian Department of Statistics). Importing fossil fuels into Jordan is contributing to the increase in

Jordan's debt by $\$ 3,575$ billion. The shift is towards the production of renewable energy by $50 \%$ of Jordan's needs of electrical energy. The trade deficit will decrease to 5.505 billion dollars, and at the same time, the debt in Jordan 
will decrease by the value of this amount. Thus, the increase

in investment in renewable energy will lead to a reduction in debt in Jordan.

\section{Recommendations}

7.1 The plan for renewable energy projects is amended in 2030 to reach $50 \%$ of Jordan's electric power instead of $14 \%$ as specified. The necessary customizations are made to configure the infrastructure for it.

7.2 The Jordanian financial system is developing to support the renewable energy industry, active financial instruments are created to use renewable energy and protect the environment, the green

the finance system is to develop effective mechanisms that coordinate the relationship between financing and renewable energy projects and the provision of government guarantees.

7.3 Investing in renewable energy projects is to raise rates. Innovation and technological development of equipment for renewable energy projects apply more efficient technologies in renewable energy production. The establishment of a data bank is about energy sources in Jordan, especially solar energy. Strategies are needed to ensure investment in renewable energy and interest in agreements with other countries and with specialized international organizations.

7.4 Self and local financing is increasing mainly for renewable energy projects. Providing mechanisms that contribute to supporting this trend, whether through tax exemptions or

providing financial guarantees. Supporting scientific research and providing the necessary capabilities for this in the field of energy. Providing qualified human resources and training to create an efficient work element that is the leader in the development and improvement process.

7.5 Companies are motivated to adopt an environmentally sustainable approach through the support provided by the banking sector, which contributes to reducing the pressures that the costs of importing renewable energy and gas from abroad pose to the Jordanian economy.

7.6 Governance is used in the successful implementation of these strategies. The complementary environment must be created along with the involvement of all key stakeholders from the energy and related sectors. The renewable energy sector is developing a future vision. (Serena Sandri \& Others,2020).

\section{References}

Azzuni, A. \& Breyer, C. (2020). Global Energy Security Index and Its Application on National Level. Energies $2020,13,2502$.

Flavio R. Arroyo M.\& \& Luis J. Miguel, (2020), The Role of Renewable Energies for the Sustainable Energy Governance and Environmental Policies for the Mitigation of Climate Change in Ecuador.Energies2020,13,3883;doi:10.3390, https://www.mdpi.com/journal/energies.

Assel K. Kozhakhmetova\& Kenzhebek T. Gabdullin \& Duissekul A. Kunanbayeva \& Samal K. Tazhiyeva1 \&Renata E. Kydaybergenova (2019), Green Energy Project's Efficiency: A Cross-industry Evaluation: International Journal of Energy Economics and Policy ISSN: 2146-4553.

Albaali, Mohammed Shahateet \& Khaled, Al-Naif \& Saud, Altayeb \& Abdul Ghafoor, Saidi (2020), Examining the Economic Impact of Renewable Energy in Green Buildings: A Case Study of Jordan International Journal of Energy Economics and Policy, 2020, 10(6), 34.

Abdelrahman,Azzuni\& Aghahosseini,Arman\& Ram, Manish\& Bogdanov, Dmitrii\&Caldera, Upeksha (2020), Energy Security Analysis for a 100\% Renewable Energy Transition in Jordan by2050.Sustainability;Basel Vol. 12, Iss. 12, (2020): 4921. DOI:10.3390/su12124921.

Abdul Hakim, Mustafa Joudeh\& Haitham I. M. Almubaideen\& Shaher Falah, (2018), Environmental disclosure in the annual reports of the Jordanian mining and extraction companies, JEFA-V.5-ISS.1-2018(3).18-25.

Chen, Zhixia\& Hossen, Md Miraj\& Sayed Sami Muzafary\& Begum, Mareum, (2018), Green Banking for Environmental Sustainability-Present Status and Future Agenda: Experience from Bangladesh, Asian Economic and Financial Review,Vol. 8, Iss. 5, (2018): 571-585. DOI: 10.18488/journal.aefr.2018.85.571.585.

Doh G.W. (2009). Low carbon green growth and evolution of finance industry. Economic Focus, 240, SERI.

Guangyou, Zhou \& Chen Liu \& Sumei Luo, (2020), Allocation Effect of Green Credit Policy: Based on DID Model. Sustainability of the Energy Sector in Jordan: Challenges and Opportunities Sustainability; Basel Vol. 12, Iss. 24, , 2020: 10465. DOI:10.3390/su122410465.

Höhne et al. (2018). Indian Innovation Lab the Mudra, Journal of Finance and Accounting, Volume 5, Issue 1, June, 2018.

Höhne , Khosla \& Fekete , Gilbert (2012), Mapping of Green Finance, IDFC Members in 2011, Ecofys.

Islas J, Manzini F\& Martínez M. CO. (2004). mitigation costs for new renewable energy capacity in the Mexican electricity sector using renewable energies, Solar Energy 2004; 76: 499-507.

Jaramillo O.\& Saldana R \& Miranda U. (2004). Wind power potential of Baja California Sur, México. Renewable Energy 2004; 29: 2087-2100. 
Jaber, J.O.\& Elkarmi, F.\& Alasis, E.\& Kostas, (2015). Employment of renewable energy in Jordan: Current status, SWOT and problem analysis. Renew Sustainable Energy Rev. 2015, 49, 490-499.

Karatayev, M.\& Clarke, M. (2014). Current energy resources in Kazakhstan and the future potential of renewables: A review Energy Procedia, 59, 97-104.

Karim, Mohammad Ershadul \& Ridoan Karim\& Islam, Md Toriqul, (2019), Renewable Energy for Sustainable Growth and Development: An Evaluation of Law and Policy of Bangladesh. Sustainability2019, 11,5774;doi:10.3390/su11205774,www.mdpi.com/journal/sustainability.

Karim, Mohammad Ershadul\& Ridoan Karim\& Islam, Md Toriqul\& Muhammad-Sukki, Firdaus\& Nurul Aini Bani, (2019), Renewable Energy for Sustainable Growth and Development: An Evaluation of Law and Policy of Bangladesh, et al. Sustainability; Basel Vol. 11, Iss. 20, (2019): 5774. DOI:10.3390/su11205774.

Liutak, O; \& Kravchuk, P. (2021). Development Of Renewable Energy In The Context Of Formation Of Innovative Economy And Energy Independence As The Geopolitical Priorities Of The State ; et al.IOP Conference Series. Earth and Environmental Science; Bristol Vol. 628, Iss. 1, Jan 2021.

Munitlak-Ivanovic, Olja\& Zubović, Jovan\& Mitić, Petar.Ekonomika \& Poljoprivrede, Lgrade, (2017), Relationship Between Sustainable Development and Green Economy, Green Finance and Banking Vol. 64, Iss. 4, (2017):pp 1467-1482.

N Leela Prasad\& P Usha Sri \& K Vizayakumar \& R Srikanth, (2021),( Performance Analysis of a Conventional and Renewable Energy based Electric Power Generation Systems - A Comparative LCA Study, IOP Conf. Series: Materials Science and Engineering 1057 (2021) 012054 IOP Publishing doi:10.1088/1757899X/1057/1/012054. 8-9.

O. Liutak1, O. Baula1 \& A. Poruchnyk, Stoliarchuk Ya.\& P. Kravchuk1 \& Iu. Kostynets, (2012), IOP Conf. Series: The Development of Renewable Energy in The Context of Formation of Innovative Economy and Energy Independence As The Geopolitical Priorities of Earth and Environmental Science 01,628 ,2021.

Parvadavardini Soundarrajani \& Nagarajan Vivek, (2021), Green finance for sustainable green economic growth in India, Mathematics Basel Vol. 9, Iss. 2, (2021): 159. DOI:10.3390/math9020159.

Paul J. Meier, (2002), Life Cycle Assessment of Electricity Generation Systems and Applications for Climate Change Policy Analysis. A dissertation submitted to University of Wisconsin - Madison.

Persiaran, Bukit Kiara \& Bukit, Kiara\& Kuala Lumpur, (2019), Islamic Green Finance Development, Ecosystem and Prospects, Securities Commission MALAYSIA 3, www.sc.com.my.

Palesa, Shipalana, (2020), Green Finance Mechanisms in Developing Countries: Emerging Practice, https://saiia.org.za/researche.

Riaz, Uddin \& Hashim, Raza Khan \& Asad, Arfeen , Muhammad, Ayaz Shirazi\& Athar Rashid \&Umar Shahbaz Khan, (2021), Energy Storage for Energy Security and Reliability through Renewable Energy Technologies: A New Paradigm for Energy Policies in Turkey and Pakistan,SustainabilityBasel Vol. 13, Iss. 5, (2021): 2823. DOI:10.3390/su13052823.

Shimla, Himachal Pradesh, (2018), Journal of Finance and Accounting, V. 5, Iss. 1.

Stephen, Spratt\& Stephany Griffith-Jones\& Jose Antonio Ocampo, ( 2013), Mobilizing Investment for Inclusive Green Growth in Low-Income Countries, giz, http://www.stephanygj.net/papers/h .

Serena, Sandri\& Hussam, Hussein\& Nooh Alshyab,(2020), Sustainability of the Energy Sector in Jordan: Challenges and Opportunities, Sustainability, 2020, vol. 12, issue 24, 1-25

Sharif, Mohd\& Vijay, Kumar Kaushal, (2018), Green Finance: A Step towards Sustainable Development(2018) July 2018, MUDRA Journal of Finance and Accounting .

Soundarrajan P.\&Vivek N. (2016). Green finance for sustainable green economic growth in India. Agric. Econ. Czech, 62: 35-44. https://doi.org/10.17221/174/2014-AGRICECON.

Zadek \& Flynn, (2013), South-Originating Green Finance: Exploring the Potential, The Geneva International Finance Dialogues, UNEP FI, SDC, and IISD.

Thomas, Schinko \& Sönke, Bohm \& Nadejda Komendantova , El Mostafa, Jamea \& Marina, Blohm, (2019), Morocco's sustainable energy transition and the role of financing costs: a participatory electricity system modeling approac . Energy, Sustainability and Society.

Upeksha, Caldera \& Dmitrii, Bogdanov\& Svetlana, Afanasyeva \& Christian Breyer,(2018),Role of Seawater Desalination in the Management of an Integrated Water and 100\% Renewable Energy Based Power Sector in Saudi Arabia, Scholarly Journals:DOI:10.3390/w10010003.

Vidal,Amaro, J J\& Ø Stergaard, P A\& Sheinbaum,Pardo, C.WIT T.(2015). Renewable Energy Sources In The Mexican Electricity System transactions on Ecology and the Environment; Southampton W Press, Vol. 195, :449-461., DOI:10.2495/ESUS150381.

Yao, Wang\& Qiang Zhia (2016), The role of green finance in environmental protection Two aspects of market mechanism and policy, Elsevier Ltd. This is an open access article under the CC BY-NC-ND license Energy Procedia 104, 311 - 316.

Zong, Woo Geem \& Sung, Yong Chung \& Jin-Hong, Kim(2016), Optimal Energy Mix with Renewable Portfolio 
Standards in Korea, Sustainability 8(5):423 DOI:10.3390/su8050423.

https://www.nepco.com.jo/store/docs/web/(2019).

https://www.emrc.gov.jo/Pages/viewpage?pageID=29( 2021).

alkhaleej.com/news/article/1219666).

(http://www.akhbar(2020).

(https://www.ecomena.org/jordan-green-ar/(2020).

(http://alrai.com/article/10454844).

https://www.imf.org/ar/News/Articles/2019/10/09/Blog-connecting-the-dots-between-sustainable-finance-and-

financial-stability.

http://www.unitjuggler.com/convert-energy-from-boe-to-kWh.html .

Bloomberg New Energy Finance.

Green finance synthesis report, G20,5 September (2016).

https://www.climatebonds.net, EIB2007. 